\title{
Adult-onset opsoclonus-myoclonus-ataxia syndrome as a manifestation of brazilian lyme disease-like syndrome: a case report and review of literature
}

\author{
Angelina Maria Martins Lino ${ }^{a, b}$, Raphael Ribeiro Spera ${ }^{a}$, Fernando Peixoto Ferraz de Campos ${ }^{b}$, \\ Christian Henrique de Andrade Freitas ${ }^{a}$, Márcio Ricardo Taveira Garciac, \\ Leonardo da Costa Lopes ${ }^{b}$, Aleksander Snioka Prokopowitsch ${ }^{b}$
}

Lino AMM, Spera RR, Campos FPF, et al. Adult-onset opsoclonus-myoclonus-ataxia syndrome as a manifestation of brazilian lyme disease-like syndrome: a case report and review of literature. Autopsy Case Rep [Internet]. 2014;4(1): 29-37. http://dx.doi.org/10.4322/acr.2014.005

\section{ABSTRACT}

Described in 1962, the opsoclonus-myoclonus-ataxia syndrome (OMAS) is a rare, neurologically debilitating disorder with distinct characteristics that may begin in childhood or adult life. Although many cases remain without etiological diagnosis, others are related to neoplasms and infectious diseases. We report a 41-year-old previously healthy male with an 8-day history of headache, vertigo, nausea, vomiting, and nystagmus. After a normal brain computed tomography and lymphocytic pleocytosis in cerebral spinal fluid (CSF), intravenous acyclovir therapy was initiated in the emergency room. On the third day of hospitalization, the diagnosis of OMAS was made based on the presence of chaotic and irregular eye movements, dysarthric speech, gait instability, generalized tremor, and myoclonic jerks. In the face of his neurological worsening, ampicillin followed by nonspecific immunotherapy (methylprednisolone and intravenous immunoglobulin) was prescribed, with mild clinical improvement. After a thorough laboratory workup, the definite diagnosis of neuroborreliosis was established and ceftriaxone (4 g/daily/3 wks) and doxycycline (200 mg/day/2 mo) was administered. Toward the end of the ceftriaxone regimen, the neurologic signs substantially improved. We believe this to be the first case description of OMAS as clinical presentation of Brazilian Lyme disease-like syndrome (Baggio-Yoshinari syndrome).

Keywords: Opsoclonus-Myoclonus Syndrome; Lyme Neuroborreliosis; Borrelia burgdorferi.

\section{CASE REPORT}

A 41-year-old male Caucasian, who has lived in the city of Sao Paulo for the last 22 years came to the emergency room with an 8-day history of continuous, intense, bilateral occipital headache associated with photophobia, nausea, and vomiting. Three days after the initial symptoms, he had fever, myalgia, and vertigo. In the following days he developed slurred speech, marked gait instability, and imbalance. His past medical history was uneventful (he denied the occurrence of oral

\footnotetext{
a Department of Neurology - Hospital das Clínicas - Faculdade de Medicina - Universidade de São Paulo, São Paulo/SP - Brazil.

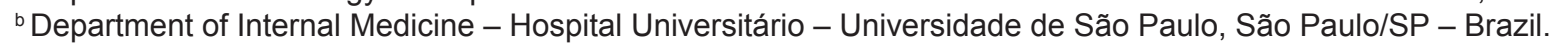

c Department of Radiology - Instituto do Câncer do Estado de São Paulo - São Paulo/SP - Brazil.
}

Copyright $\odot 2014$ Autopsy and Case Reports - This is an Open Access article distributed of terms of the Creative Commons Attribution NonCommercial License (http://creativecommons.org/licenses/by-nc/3.0/) which permits unrestricted non-commercial use, distribution, and reproduction in any medium provided article is properly cited. 
or genital ulcers, arthritis, or any skin lesions preceding the recent symptoms). He was not on any medication and denied alcoholism, smoking, use of illicit drugs, or neurologic complaints in the past. He had no familial history of neurologic disease. He has six cats that are well maintained and regularly vaccinated. He denied traveling during the last 2 years, but used to go camping between the age of 27 and 31 to a region where there were tick infestations.

At the emergency room, the remarkable physical findings included an ataxic gait, which worsened with the Tandem maneuver, dysarthric speech, and nystagmus to the right. Brain computed tomography (CT) was normal, and the analysis of cerebral spinal fluid (CSF) revealed lymphocytic pleocytosis with 528 cells $/ \mathrm{mm}^{3}$ ( $91 \%$ of lymphocytes, $8 \%$ monocytes, and $1 \%$ neutrophils), protein was $76.3 \mathrm{mg} / \mathrm{dL}$ (reference value [RV]: $<40$ $\mathrm{mg} / \mathrm{dL}$ ), glucose was $50 \mathrm{mg} / \mathrm{dL}$ (plasma glucose $94 \mathrm{mg} / \mathrm{dL}, \mathrm{RV}:>2 / 3$ plasma glucose). Chloride and lactate values were in the reference range. Gram stain, China ink, cultures for acid-fast bacilli, fungus, and usual bacteria were all negative. Although the clinical course was not characteristic for herpetic meningoencephalitis, intravenous acyclovir was started.

On the third day of hospitalization, despite the maintenance of normal mental status, the patient presented involuntary, fast, arrhythmic, conjugated, multidirectional eye movements preventing him from fixing his gaze (opsoclonus) [video]. He also developed generalized rhythmic resting and action tremors associated with myoclonic jerks at postural fixation, and volitional limb movements, particularly in the right side. The cerebellar signs worsened, appearing as marked truncal-limb dyssynergia, bilateral limb dysmetria, dysdiadochokinesia, and cerebellar ataxia, which progressed to astasia and abasia. The motor and sensory examination (deep and superficial sensations) was unremarkable, as were all the deep tendon reflexes. The autonomic function and cranial nerves examinations were also unremarkable, except for hearing loss. The patient was unable to stand and walk, and became completely dependent for daily activities, such as eating, brushing teeth, shaving, and bathing.

Based on these neurological signs, the diagnosis of opsoclonus-myoclonus-ataxia syndrome (OMAS) was raised and a wide diagnostic workup was carried out to identify unusual infectious agents and immune dysfunction, the more common cause of this syndrome in adults. Sodium valproate was prescribed for the relief of myoclonic movements. Ampicillin was empirically started in consideration of the diagnostic possibility of Listeria rhomboencephalitis and acyclovir was withdrawn. A new CSF test confirmed the lymphocytic pleocytosis with 210 cells $/ \mathrm{mm}^{3} \quad(99 \%$ lymphocytes, $1 \%$ neutrophils), protein was $84.7 \mathrm{mg} / \mathrm{dL}$, glucose was $51 \mathrm{mg} / \mathrm{dL}$, lactate and chloride values were within normal limits, adenosine deaminase was $3.05 \mathrm{UI} / \mathrm{L}$ (RV: $9 \mathrm{UI} / \mathrm{L}$ ). In spite of the partial decrease in CSF cellularity, the patient's neurological deficits were unchanged. Methylprednisolone (1g/day/5 days) regimen was administered followed by a 5-day course of intravenous immunoglobulin $(400 \mathrm{mg} / \mathrm{kg} /$ day) with mild clinical improvement.

Cranial magnetic resonance imaging (MRI) showed a tenuous, poorly defined, oval-shaped hyper signal lesion in fluid-attenuated inversionrecovery (FLAIR) and T2-weighted sequences, measuring $1.5 \mathrm{~cm}$, with no diffusion restriction or enhancement after contrast infusion, in the left thalamus. No abnormal signs were found in the brainstem, cerebellum, or cranial nerves (Figure 1).

The electroencephalogram was normal. At the brainstem auditory evoked potential test, delay was registered in all wave latencies for the right ear, and in waves III and V for the left ear. However, all interpeak latencies were normal on both sides, indicating a distal cochlear nerve dysfunction in the right ear with preservation of intra-brainstem auditory pathways.

Contrast abdominal, thoracic, and pelvic CT, as well as testicular ultrasonography, failed to demonstrate any abnormalities suggestive of neoplasia. Prostate-specific antigen determination was within normal limits.

Renal and liver function tests, electrolytes, hepatic enzymes, blood cell count, lactic dehydrogenase (LDH), free-thyroxin, thyroid stimulating hormone (TSH), immunoglobulin dosage and protein electrophoresis were all non-contributory. Laboratory exams for systemic inflammatory activity disclosed C-reactive protein maximum value of $30 \mathrm{mg} / \mathrm{L}$ ( $\mathrm{RV}:<5 \mathrm{mg} / \mathrm{L}$ ) and erythrocyte sedimentation rate of $30 \mathrm{~mm}$ in the first hour ( $R V<15 \mathrm{~mm}$ in the first hour). ANA tested by indirect immunofluorescence with Hep-2 cells was unremarkable as was the test for rheumatoid factor. 


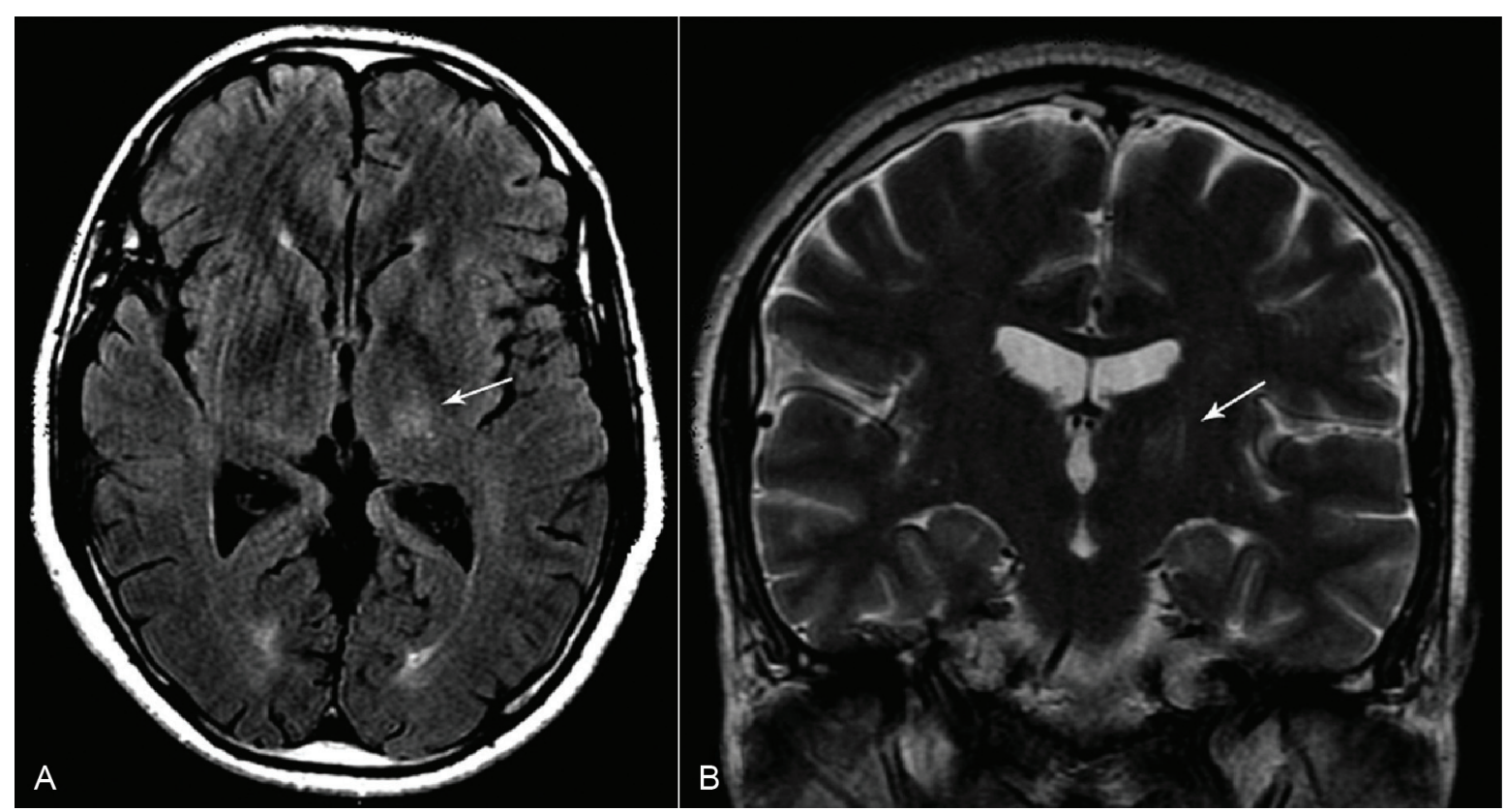

Figure 1 - Cranial MRI. A - FLAIR axial imaging; B - T2 coronal imaging. Both images show a tenuous hyper-signal in the left thalamic region (arrows) compatible with vasogenic edema or gliosis. Note the lack of interruption of the hematoencephalic barrier or cytotoxic edema.

Syphilis test results were negative in blood and CSF as well as cultures for fungus and bacteria. A polymerase chain reaction assay for Herpes virus 1, 2, and 6, Varicella zoster virus, cytomegalovirus, and Mycobacterium tuberculosis in the CSF were all negative. Immunological tests for HIV were negative in blood and CSF, and the immunological window was ruled out by a negative viral load count. Serological tests for Dengue virus, Hepatitis B and C virus, Leptospira sp. were negative. Serology for Epstein Barr virus, toxoplasmosis, and rubella showed positivity for IgG but negativity for IgM.

In the meantime, the immunologic reaction (IgM) for Borrelia burgdorferi was positive in the CSF by enzyme-linked immunosorbent assay (ELISA) but negative in the serum (ELISA and Western Blott) performed in the Brazilian Lyme Disease Reference Laboratory ${ }^{1}$. With this result, the diagnosis of neuroborreliosis was highly considered and ceftriaxone ( $2 \mathrm{~g} /$ day) therapy was instituted for 3 weeks, followed by doxycycline $100 \mathrm{mg}$ twice daily for 2 months. After 7 days of use of ceftriaxone, the cerebellar signs and opsoclonus improved [video 2], the myoclonic jerks disappeared, and the patient was able to stand up and walk with assistance.

\footnotetext{
1 Medical Research Laboratory in Rheumatology - LIM 17 - Faculdade de Medicina da Universidade de São Paulo
}

\section{DISCUSSION}

\section{Opsoclonus-Myoclonus-Ataxia Syndrome (OMAS)}

In 1962, Marcel Kinsbourne, ${ }^{1}$ an Austrianborn pediatric neurologist, described six children with acute onset of a distinctive movement disorder, which was initially coined as myoclonic encephalopathy or Kinsbourne syndrome, and further known as "Dancing eyes syndrome, ${ }^{2-4}$ opsoclonus-myoclonus, ${ }^{5}$ and ataxia opsoclonusmyoclonus. ${ }^{6}$ The Children's Cancer Group study finally called this entity opsoclonus-myoclonusataxia syndrome..$^{7,8}$

OMAS is a rare and debilitating neurologic disease, showing acute or subacute onset in childhood or adult life, occurring in 1-2 people per 10 million per year. ${ }^{9-11}$ Opsoclonus is an important marker and a diagnostic clue for this syndrome. It is characterized by involuntary, chaotic, multidirectional, fast, conjugated eye movements (saccades), particularly pronounced when the patient tries to fix the gaze, but is also present at smooth pursuit and convergence, and could persist during sleep or eyelid closure. ${ }^{12}$ Although the pathophysiology is uncertain, the most accepted hypothesis suggests that disinhibition of the fastigial nucleus in the cerebellum due to dysfunction of Purkinje cells in 
the dorsal vermis or their inhibitory projections to the fastigial nucleus. ${ }^{12}$ Thus, affecting this network can cause opsoclonus independently of any etiological factor. Often, opsoclonus is accompanied by myoclonus, characterized by sudden, brief, shocklike involuntary movements, typically postural or movement-induced, compromising the trunk, the upper and lower limbs more frequently, but also may occur in the face, tongue, and palate. ${ }^{13-15}$ The myoclonic jerks can be so intense that they cause incoordination and falls, and can hamper the classical signs of cerebellar dysfunction, such as imbalance, dysarthria, and dysmetria. Thus, the ataxia (gait instability or imbalance) could result from myoclonus, cerebellar involvement, or both. To these three cardinal signs, cognitive, behavioral, and variable degrees of encephalopathy may also be associated. All these neurological signs are not necessarily present together at the onset of the syndrome.

In children, the OMAS occurs equally in both genders, commonly before 3 years of age. In about half of patients it is seen as a paraneoplastic syndrome most commonly associated with neuroblastic tumors, with neuroblastoma in more than half the pediatric cases..$^{1,10,16-18}$ Infectious, postinfectious, post-vaccinal, and idiopathic cases were also reported. The clinical presentation, detection of autoantibodies, response to immunosuppressive treatment, and the long-term outcome are similar concerning the idiopathic and neuroblastomaassociated cases. ${ }^{18}$ Neuroblastoma-associated OMAS is frequently has a favorable prognosis., Long-term follow-up studies have shown normal or near-normal motor outcome along with cognitive and neuropsychological deficits (language, attention, memory, visuomotor, and working memories) in almost $80 \%$ of pediatric patients. ${ }^{6,7,18}$ The identified risk factors for worse outcome were younger age, severe initial presentation, delayed immunosuppressive treatment, and relapses with steroid-dose tapering. ${ }^{18,19}$

Adult-onset OMAS is much less frequent. The literature is limited to case reports and small series that showed no gender predominance and 48.5 years (range 18-80 years) as median age of onset. ${ }^{2,15}$ In general, the disease progresses rapidly within a median time of 4 weeks with severe disability in most patients. In about $35 \%$ of patients other coexisting neurological signs may be associated, including mild behavioral, cognitive, and/or mood changes; encephalopathy; cranial nerve palsies; seizure; or Lambert-Eaton myasthenic syndrome. .,15,20 $^{\text {The }}$ clinical presentation and the early severe disability of the case reported herein were in accordance with published data.

In over $50 \%$ of adult patients, OMAS is a paraneoplastic presentation, with smallcell lung, breast, and ovarian cancers the most commonly identified neoplasms. ${ }^{2,15}$ Rarer oncologic associations include melanoma, ${ }^{21-23}$ and other neoplasms of the gynecologic tract, ${ }^{10,24-27}$ as well as cancers of the urologic,,$^{15,28,29}$ hematologic, ${ }^{30-32}$ and gastrointestinal systems. ${ }^{15}$ Infections (mainly virus), idiopathic cases, and rarely toxic or metabolic disturbances account for the other half. In our case, an infectious cause was identified after an extensive laboratory investigation.

In both idiopathic and paraneoplastic cases, the imaging diagnostic workup generally shows normal CT and MRI. ${ }^{2,15}$ In our case, the MRI showed a tenuous and unspecific thalamic hyper-signal in T2-weighted and FLAIR sequences. Even though the same findings had been described in one idiopathic case by Bataller et al., ${ }^{15}$ Kobayashi et al. ${ }^{33}$ found thalamic lesions in the autopsy of a Borrelia burgdorferi-seropositive chronic encephalomyelopathy. Furthermore, blood and CSF tests are most useful in diagnosing an infection, but do not confirm or exclude a paraneoplastic or autoimmune etiology. Among the cases of immunologic etiology, CSF analysis may show normal results or mild increase in protein (47-137 mg/dl) and/or lymphocytic pleocytosis (8$\left.98 \mathrm{cells} / \mathrm{mm}^{3}\right){ }^{2}$ Higher cell counts do not rule out idiopathic or paraneoplastic causes, but should raise the suspicion of an isolated or associated infection as observed in our patient. In four previously reported patients with Borrelia-associated OMAS, the cell counts ranged from 28 to 244 cells $/ \mathrm{mm}^{3}$ and the remaining CSF characteristics were very similar to our case. ${ }^{34-37}$

The pathophysiology of the OMAS remains obscure. In idiopathic and paraneoplastic cases, the tissue dysfunction has been attributed to humoral and/or cellular immune attack affecting the structures belonging to fastigial nucleus-Purkinje cells network. In this setting, several antibodies against cell surface or intracellular structures of nervous system have been identified, such as, glycine receptor, $\mathrm{Hu}$ (ANNA-1), $\mathrm{Ri}$ (ANNA-2), glutamate receptor, neurofilament, Yo, Ma1, Ma2, amphiphysin, CRMP-5/anti-CV2, and Zic. 2,15,20,32,38-45 Although these antibody studies have contributed to understanding of immunopathogenesis, most 
OMAS patients present negative results in blood and CSF, limiting their diagnostic value. In addition, $B$ and $T$ cells expansion, favorable response to rituximab therapy, and OMAS occurrence during immune reconstitution phase in HIV infection have raised the role for cell-mediated mechanisms. ${ }^{46-48}$

Parainfectious causes may be diverse and include agents such as cytomegalovirus, EBV, Coxsackie virus, West Nile virus, HIV, varicella-zoster virus, Influenza A virus, hepatitis C virus, Mycoplama pneumoniae, Salmonella sp., Ricketsia, group A streptococci, mumps, Lyme Disease (LD), and psittacosis. ${ }^{2,10,14,17,34,36,49-59}$ OMAS was also described after measles, mumps, and rubella vaccine..$^{60}$ In HIV infection, Kanjanasut et al. ${ }^{57}$ suggest that OMAS occurs at the time of seroconversion or during the immune reconstitution inflammatory response, what justified the request of HIV viral load count in the presence of a negative serology detected in our patient.

\section{Borreliosis}

LD is a well-known infectious disease in the USA and Europe. In 1975, Steere et al. ${ }^{61}$ described 51 patients with arthritis of unknown cause and hypothesized an arthropod transmission, possibly a tick, due to findings of skin lesions in $25 \%$ of the patients. This lesion was similar to erythema chronicum migrans reported in 1909 in Europe, which had been associated with tick bites and clinical manifestations such as neuropathic pain, paralysis, or meningitis. From 1975 to 1984, the Yale University group reported the clinical spectrum of LD, which included the nervous system, the heart, and the joints. ${ }^{62}$

The infectious agent in LD was identified in 1982 by Burgdorfer et al. ${ }^{63}$ and further named as Borrelia burgdorferi (sensu stricto). Nowadays, tick-borne Borrelia spp. encompass three major phylogenetic groups, of which the Lyme borreliosis group-formerly named $B$. burgdorferi sensu latohas 19 species with at least 10 being pathogenic to human beings. ${ }^{64}$ In North America, B. burgdorferi sensu stricto is the main LD pathogenic agent, while in Europe there are at least five pathogenic species, causing a wide clinical spectrum.

Clinically, LD is conceptually divided into early and late phases, and chronic or postLyme borreliosis syndrome. The early-LD can be localized or disseminated, defined by the occurrence of erythema migrans, neuroborreliosis, carditis, or lymphocytoma. ${ }^{65}$ In the late-LD the usual manifestations are arthritis without neurological disease, acrodermatitis chronica atrophicans, or rarely central or peripheral neurological deficits. Chronic Lyme disease is poorly defined and most associated with persistent pain, fatigue, or neurocognitive complaints. ${ }^{65}$

In considering the extreme difficulty in demonstrating Borrelia organisms by PCR and cultures of CSF, and in view of dramatic clinical improvement with antimicrobial therapy, it was hypothesized that tissue-adhered spirochete, mainly in oligodendrocytes, is essential for disease manifestations, and the tissue damage is amplified by local immune response that encompasses expression of several pro-inflammatory cytokines and antibodies generated in some extent by molecular mimicry. ${ }^{66}$

Borreliosis' laboratory workup is sometimes challenging since it relies on indirect detection methods. ${ }^{67}$ ELISA is the method for specific antibodies screening followed by immunoblot when samples are ELISA-positive, in the serum. Diagnostic sensitivity of ELISA for acute Borreliosis ranges from $70 \%$ to $90 \% .{ }^{67}$ Intrathecal detection of Borreliaspecific antibody is important for neuroborreliosis diagnosis. These antibodies are exclusively detected in the cerebrospinal fluid (CSF) in 10\% to $70 \%$ of the patients. ${ }^{68,69}$ When these antibodies are detected in both, serum and CSF, the antibodyindex ${ }^{67,70}$ will diagnose the intrathecal specificantibody production with $80 \%$ of sensitivity. This index is useful for the cases with less than 6-month of disease. Protein chain reaction and cultures may be useful in early infection, but microscope-based assays, lymphocyte transformation test, and others are not currently recommended. Considering the European criteria ${ }^{67}$ for neuroborreliosis (Table 1), our patient received the diagnosis of definite neuroborreliosis.

In Brazil, the study of LD started in 1989 and until now much of the knowledge on Brazilian borreliosis is due to the research effort of a multidisciplinary team headed by Dr. Natalino $\mathrm{H}$. Yoshinari. ${ }^{68,71}$ In a preliminary study of 19 patients, Yoshinari and coworkers found that $31.5 \%$ had skin lesions, $31.5 \%$ had arthritis, and $42 \%$ had neurological disorders. ${ }^{70}$ Particularly analyzing the neurological manifestation in 30 patients with Brazilian borreliosis, the same group showed 
Table 1 - Suggested criteria for diagnosis of neuroborreliosis ${ }^{67}$

\begin{tabular}{lc}
\hline $\begin{array}{c}\text { Diagnostic } \\
\text { category }\end{array}$ & Criteria fulfilled \\
\hline & All three \\
& $\begin{array}{l}\text { Neurological symptoms without other } \\
\text { obvious reasons } \\
\text { D Cerebrospinal fluid pleocytosis } \\
\text { Definite }\end{array}$ \\
& Tntrathecal Borrelia-antibody production \\
\hline Possible & Two of the above criteria \\
\hline
\end{tabular}

meningismus, motor and/or sensory polyradiculitis, and peripheral nerve palsies in the early and late phases of the disease. In this series, ocular symptoms were reported in $37.5 \%$ of cases and occurred more commonly in the early phase. This involvement included eyelid ptosis, anisocoria, strabismus, and ophthalmoparesis, among others. ${ }^{72}$ The clinical presentation and outcome of patients with Brazilian borreliosis were very similar of that previously reported in the USA and Europe, despite epidemiological, clinical and laboratorial differences. The contributions of the Yoshinari group can not be overemphasized. They clarified the intriguing characteristics of Borrelia spp causing LD-like syndrome in Brazil, suggesting the existence of a new exotic tick borne disease in the country, different from classical zoonosis observed in Europe and USA. ${ }^{73}$

Nowadays due to epidemiological, etiological and clinical particularities, Brazilian borreliosis is named Lyme disease-like syndrome, Infectiousreactive Lyme disease-like syndrome or BaggioYoshinari syndrome. Ticks responsible for disease transmission do not belong to Ixodes ricinus complex and etiological agent belong to $B$. burgdorferi sensu lato complex or can be a new Borrelia specie different from those spirochetes composing classical complex. Clinically, Brazilian borreliosis can evolve with a long period of latency following acute infection and other distinguishing features include higher incidence of associated autoimmune disturbances. Brazilian researches suggest that Brazilian Borrelia spp is found at atypical morphologies known as cell wall deficient bacteria, justifying clinical and laboratorial particularities. ${ }^{68}$

Reviewing three adult cases of OMAS as a manifestation of LD previously reported in English literature, ${ }^{34,36}$ some similarities were found in our case. All presented with acute onset, fast progression, and the emergency treatment was acyclovir. Specific treatment was only started after a positive result of immunologic reaction for Borrelia; our patient showed an important improvement after ceftriaxone in accordance with reported patients.

\section{CONCLUSION}

OMAS best treatment should always be, whenever possible, directed to the etiology. In idiopathic and paraneoplastic cases, the treatment and outcome are hard to evaluate and compare due to large drug variability among different series, as well as the number of cases in each series. Treatment options include high-dose corticosteroid, intravenous immunoglobulin, and plasmapheresis, isolated or combined. ${ }^{2}$ In general, parainfectious OMAS cases have a favorable prognosis and full recovery. ${ }^{59,74}$ In the literature, neuroborreliosis has been treated with parenteral antibiotics (ceftriaxone), although some European studies have suggested that oral doxycycline is as effective as ceftriaxone. ${ }^{65}$

To the best of our knowledge, this is the first case report of neuroborreliosis manifested as OMAS in Brazil, and probably the sixth case in the English language literature. Therefore, the authors call attention to this diagnostic possibility when searching the etiology of OMAS.

\section{ACKNOWLEDGEMENTS}

The authors would like to thank Nadia N. Mangini, M.D and Laura Guilhoto, MD, for interpretation of brainstem auditory evoked potencial and the electroencephalogram.

\section{REFERENCES}

1. Kinsbourne M. Myoclonic encephalopathy of infants. J Neurol N Psy. 1962;25:271-6. http://dx.doi.org/10.1136/jnnp.25.3.271

2. Klass JP, Ahlskog JE, Pittock SJ, et al. Adult-onset Opsoclonus-myoclonus Syndrome. Arch Neurol. 2012;69:1598-607. PMid:22986354. http://dx.doi.org/10.1001/ archneurol.2012.1173

3. Wilken B, Baumann M, Bien CG, Hero B, Rostasy K, Hanefeld F. Chronic relapsing opsoclonus-myoclonus syndrome: Combination of cyclophosphamide and dexamethasone pulses. Eur J Paediatr Neurol. 2008;12:51-5. PMid:17625938. http://dx.doi.org/10.1016/j.ejpn.2007.05.005 
4. Cushing $\mathrm{H}$, Wolbach SB. The transformation of a malignant paravertebral sympathicoblastoma into a benign ganglioneuroma. Am J Pathol. 1927;3:2003-5.

5. Talon P, Stoll C. Opso-myoclonus syndrome of infancy: new observations - review of the literature 110 cases. Pediàtrie. 1985;40:441-9. PMid:3835536.

6. Pinsard N, Pons-Cerdan C, Mancini J, Livet MO, Bernard R. Ataxia-opsoclonus-myoclonus syndrome. Sem Hop. 1981;57:488-94. PMid:6261394.

7. Rudnick E, Khakoo Y, Antunes NL, et al. Opsoclonusmyoclonus-ataxia syndrome in neuroblastoma: Clinical outcome and antineuronal antibodies - a report from the children's cancer group study. Med Pediatr Oncol. 2001;36:612-22. PMid:11344492. http://dx.doi.org/10.1002/ mpo. 1138

8. Cooper R, Khakoo Y, Matthay KK, et al. Opsoclonusmyoclonus-ataxia syndrome in neuroblastoma: histopathologic features - a report from the Children's Cancer Group. Med Pediatr Oncol. 2001;36:623-9. PMid:11344493. http://dx.doi. org/10.1002/mpo.1139

9. Watret A, Al-Memar A. Post infective opsoclonus myoclonus ataxia syndrome (OMAS) in Adults is a treatable condition. J Neurol Neurosurg Psychiatry. 2011;82:e4. http://dx.doi. org/10.1136/jnnp-2011-300645.5

10. Ahuja R, Kumar R, Shukla R, Shukla R, Ahuja RC. Opsoclonus-myoclonus syndrome caused by varicella-zoster virus. Ann Indian Acad Neurol. 2010;13:211-2. PMid:21085535 PMCid:PMC2981762. http://dx.doi.org/10.4103/09722327.70876

11. Pang KK, De Sousa C, Lang B, Pike MG. A prospective study of the presentation and management of dancing eye syndrome/opsoclonus-myoclonus syndrome in the United Kingdom. Eur J Paediatr Neurol. 2010;14:156-61. PMid:19423368. http://dx.doi.org/10.1016/j.ejpn.2009.03.002

12. Wong AM1, Musallam S, Tomlinson RD, Shannon $\mathrm{P}$, Sharpe JA. Opsoclonus in three dimensions: oculographics, neuropathologic and modeling correlates. J Neurol Sci. 2001;189:71-81. http://dx.doi.org/10.1016/S0022$510 \times(01) 00564-0$

13. Caviness JN, Forsyth PA, Layton DD, McPhee TJ. The movement disorder of adult opsoclonus. Mov Disord. 1995;10:22-7. PMid:7885352. http://dx.doi.org/10.1002/ mds. 870100106

14. Digre KB. Opsoclonus in adults: report of three cases and review of literature. Arch Neurol. 1986;43:1165-75. http:// dx.doi.org/10.1001/archneur.1986.00520110055016

15. Bataller L, Graus F, Saiz A, Vilchez JJ. Spanish OpsoclonusMyoclonus Study Group: clinical outcome in adult onset idiopathic or paraneoplastic opsoclonus-myoclonus. Brain 2001;124(pt 2):437-43. PMid:11157570. http://dx.doi. org/10.1093/brain/124.2.437

16. Mitchel WG, Davalos-Gonzales Y, Brumm VL, et al. Opsoclonus-ataxia caused by childhood neuroblastoma: developmental and neurological sequelae. Pediatrics 2001;109:86-98.
17. Bonnet L, Medeiros de Bustos E, Moulin T. Syndrome opsoclonus myoclonus chez l'adulte. Rev Neurol. 2012;168:987-8. PMid:22682052. http://dx.doi.org/10.1016/j. neurol.2012.03.005

18. Tate ED, Allinson TJ, Prazantelli MR, Verhulst SJ. Neuroepidemiologic trends in 105 US cases of pediatric opsoclonus-myoclonus syndrome. J Pediatr Oncol Nurs. 2005;22:8-19. PMid:15574722. http://dx.doi. org/10.1177/1043454204272560

19. Brunklaus A, Pohl K, Zuberi SM, de Sousa C. Outcome and prognostic features in opsoclonus-myoclonus syndrome from infancy to adult life. Pediatrics. 2011;128:E388-94. PMid:21788225. http://dx.doi.org/10.1542/peds.2010-3114

20. Wirtz PW, Smitt PAES, Hoff J, et al. Anti-Ri antibody positive myoclonus in a male patient with breast carcinoma. J Neurol. 2002;249:1710-12. PMid:12529794. http://dx.doi.org/10.1007/ s00415-002-0913-z

21. Berger JR, Mehari E. Paraneoplastic opsoclonus-myoclonus secondary to malignant melanoma. J Neurooncol. 1999;41:435. http://dx.doi.org/10.1023/A:1006189210197

22. Jung KY, Youn J, Chung CS. Opsoclonus-myoclonus syndrome in an adult with malignant melanoma. J Neurol. 2006;253:942-3. PMid:16715202. http://dx.doi.org/10.1007/ s00415-006-0026-1

23. Hauspy J, Nevin A, Harley I, et al. Paraneoplastic syndrome in vaginal melanoma: a case report and review of the literature. Int J Gynecol Cancer. 2007;17:1159-63. PMid:17309666. http://dx.doi.org/10.1111/j.1525-1438.2006.00857.x

24. Scholz J, Vieregge P, Ruff C. Paraneoplastic opsoclonusmyoclonus syndrome in metastatic ovarian carcinoma. J Neurol Neurosurg Psychiatry. 1994;57:763-4. http://dx.doi. org/10.1136/jnnp.57.6.763-a

25. Jongen JL, Moll WJ, Sillevis Smitt PA, Vecht CJ, Tijssen CC. Anti-Ri positive opsoclonus-myoclonus-ataxia in ovarian duct cancer. J Neurol. 1998;245:691-2. http://dx.doi.org/10.1007/ s004150050270

26. Moretti R, Torre P, Antonello RM, Nasuelli D, Cazzato G. Opsoclonus-myoclonus syndrome: gabapentin as a new therapeutic proposal. Eur J Neurol. 2000;7:455-6. http:// dx.doi.org/10.1046/j.1468-1331.2000.00091.x

27. Lou E, Hensley ML, Lassman AB, Aghajanian C. Paraneoplastic opsoclonus-myoclonus syndrome secondary to immature ovarian teratoma. Gynecol Oncol. 2010;117:382-4. PMid:20144470. http://dx.doi.org/10.1016/j.ygyno.2010.01.017

28. De Luca S, Terrone C, Crivellaro S, et al. Opsoclonusmyoclonus syndrome as a paraneoplastic manifestation of renal cell carcinoma: a case report and review of the literature. Urol Int. 2002;68:206-8. http://dx.doi.org/10.1159/000048454

29. Pittock SJ, Lucchinetti CF, Lennon VA. Anti-neuronal nuclear autoantibody type 2: paraneoplastic accompaniments. Ann Neurol. 2003;53:580-7. PMid:12730991. http://dx.doi. org/10.1002/ana.10518

30. Kumar A, Lajara-Nanson WA, Neilson RW Jr. Paraneoplastic opsoclonus-myoclonus syndrome: initial presentation of 
non-Hodgkin's lymphoma. J Neurooncol. 2005;73:43-5. PMid:15933816. http://dx.doi.org/10.1007/s11060-004-2465-9

31. Gabaldon-Torres L, Fernandez-Domingues J, Salas-Felipe $\mathrm{J}$, et al. Opsoclonus-myoclonus ataxia syndrome: two anatomo-clinical case reports. Rev Neurol. 2009;48:137-40. Spanish PMid:19206061.

32. Ducrocq X, Petit J, Taillander L, et al. Paraneoplastic opsoclonus-myoclonus syndrome revealing T-cell lymphoma. Presse Med. 1999;28:330-3. PMid:10083874.

33. Kobayashi K, Mizukoshi C, Aoki T, et al. Borrelia burgdorferiseropositive chronic encephalomyelopathy: Lyme neuroborreliosis? An autopsied report. Dement Geriatr Cogn Disord.1997;8:384-90. http://dx.doi.org/10.1159/000106659

34. Peter L, Jung J, Tilikete C, Ryvlin P, Mauguiere F. Opsoclonusmyoclonus as a manifestation of Lyme disease. J Neurol Neurosurg Psychiatr. 2006;77:1090-1. PMid:16914760 PMCid:PMC2077735. http://dx.doi.org/10.1136/ jnnp.2006.091728

35. Vukelic D, Bozinovic D, Morovic M, et al. Opsoclonusmyoclonus in a child with neuroborreliosis. J Infect. 2000;40:189-91. http://dx.doi.org/10.1016/S01634453(00)80016-X

36. Skeie GO, Eldøen G, Skeie BS, Midgard R, Kristoffersen EK, Bindoff LA. Opsoclonus-myoclonus syndrome in two cases with neuroborreliosis. Eur J Neurol. 2007;14:e1e2. PMid:18028183. http://dx.doi.org/10.1111/j.14681331.2007.01959.x

37. van Erp WS, Bakker NA, Aries MJH, Vroomen PCAJ. Opsoclonus and multiple cranial neuropathy as a manifestation of neuroborreliosis. Neurology. 2011;77:1013-4. PMid:21865581. http://dx.doi.org/10.1212/ WNL.0b013e31822cfc7c

38. Fadare O, Hart HJ. Anti-Ri antibodies associated with short term memory deficits and a mature cystic teratoma of the ovary. Int Semin Surg Oncol. 2004;1:11. PMid:15537431 PMCid:PMC534089. http://dx.doi.org/10.1186/1477-7800-1-11

39. Luque FA, Furneaux HM, Ferziger R, et al. Anti-Ri: an antibody associated with paraneoplastic opsoclonus and breast cancer. Ann Neurol. 1991;29:241-51. PMid:2042940. http://dx.doi.org/10.1002/ana.410290303

40. Hersh B, Dalmau J, Dangond F, Gultekin S, Geller E, Wen PY. Paraneoplastic opsoclonus-myoclonus associated with anti-HU antibody. Neurology. 1994;44:1754-5. http://dx.doi. org/10.1212/WNL.44.9.1754

41. Kambe T, Yukitoshi T, Yoshiaki F. A mild form of adultonset opsoclonus-myoclonus syndrome associated with antiglutamate receptor antibodies. JAMA Neurol. 2013;70:654-5. PMid:23699953. http://dx.doi.org/10.1001/ jamaneurol.2013.59

42. Connolly AM, Pestronk A, Mehta S, Pranzatelli MR 3rd, Noetzel MJ. Serum autoantibodies in childhood opsoclonusmyoclonus syndrome: an analysis of antigenic targets in neural tissues. J Pediatr. 1997;130:878-84. http://dx.doi. org/10.1016/S0022-3476(97)70272-5
43. Noetzel M, Cawley LP, James YL, Minard BJ, Agrawal $\mathrm{HC}$. Anti-neurofilament protein antibodies in opsoclonusmyoclonus. J. Neuroimmunol. 1987;15:137-45. http://dx.doi. org/10.1016/0165-5728(87)90088-9

44. Jomir L, Sirvain S, Bouly S, Garrido JF, Halle O. Syndrome opsoclonus-myoclonies: à propos d'un cas. Rev Med Interne.. 2009;30:980-1. PMid:19695745. http://dx.doi.org/10.1016/j. revmed.2008.11.016

45. Candler PM, Dale RC, Griffin S, et al. Poststreptococcal opsoclonus-myoclonus syndrome associated with antineuroleukin antibodies. J. Neurol. Neurosurg. Psychiatr. 2006;77:507-12. PMid:16543530 PMCid:PMC2077526. http://dx.doi.org/10.1136/jnnp.2005.078105

46. Pranzatelli MR, Travelstead AL, Tate ED, et al. B- and T-cell markers in opsoclonus-myoclonus syndrome. Neurology. 2004;62:1526-32. http://dx.doi.org/10.1212/WNL.62.9.1526

47. Pranzatelli MR, Tate ED, Travelstead AL, et al. Rituximab (anti-CD-20) adjunctive therapy for opsoclonus-myoclonus syndrome. J Pedriatr Hematol Oncol. 2006;28:58593. PMid:17006265. http://dx.doi.org/10.1097/01. mph.0000212991.64435.f0

48. van Thorn R, Rabie H, Warwick JM. Opsoclons-myoclonus in an HIV-infected child on antiretroviral therapy - possible immune reconstitution inflammatory syndrome. Eur J Paediatr Neurol. 2005;9:423-6. PMid:16269259. http:// dx.doi.org/10.1016/j.ejpn.2005.06.007

49. Morita A, Ishihara M, Kamei S, Ishikawa H. OpsoclonusMyoclonus syndrome following Influenza A infection. Intern Med. 2012;51:2429-31. http://dx.doi.org/10.2169/ internalmedicine.51.7627

50. Blue SK, Janneway R, Stanley JA. Opsoclonus and body tremulousness: a case report with suggested cause. Trans Am Neurol Assoc.1971;96:208-10. PMid:4333997.

51. Mesraoua B, Abbas M, D'Souza A, et al. Adult Opsoclonusmyoclonus syndrome following Mycoplasma pneumoniae infection with dramatic response to plasmapheresis. Acta Neurol Belg. 2011;111:136-8. PMid:21748933.

52. Vejjajiva A, Lerdverasirikul P. Opsoclonus in salmonella infection. Br Med J.1977;2:1260. http://dx.doi.org/10.1136/ bmj.2.6097.1260

53. Flabeau O, Meissner W, Foubert-Samier A, et al. Opsoclonus myoclonus syndrome in the context of Salmonelosis. Mov Disord. 2009;24:2306-8. PMid:19845009. http://dx.doi. org/10.1002/mds.22832

54. Jones CE, Smyth DPL, Faust SN. Opsoclonus-myoclonus syndrome associated with group a streptococcal infection. Pediatr Infect Dis J. 2007;26:358-9. PMid:17414405. http:// dx.doi.org/10.1097/01.inf.0000258617.23108.ba

55. Zaganas I, Prinianakis G, Xirouchaki N, Mavridis M. Opsoclonus-myoclonus syndrome associated with cytomegalovirus encephalitis. Neurology. 2007;68:1636. PMid:17485656. http://dx.doi.org/10.1212/01. wnl.0000262766.50747.27 
56. Verma A, Brozman B. Opsoclonus-myoclonus syndrome following Epstein-Barr virus infection. Neurology. 2002;58:1131-2. http://dx.doi.org/10.1212/WNL.58.7.1131

57. Kanjanasut N, Phanthumchinda K, Bhidayasiri R. HIV-related opsoclonus-myoclonus-ataxia syndrome: report on two cases. Clin Neurol Neurosurg. 2010;112:572-4. PMid:20427123. http://dx.doi.org/10.1016/j.clineuro.2010.03.024

58. Ertekin V, Tan H. Opsoclonus-myoclonus syndrome attributable to hepatitis $\mathrm{C}$ infection. Pediatr Neurol. 2000;42:441-2. PMid:20472199. http://dx.doi.org/10.1016/j. pediatrneurol.2010.02.009

59. Huber MB, Strozzi S, Steinlin M, Aebi C, Fluri S. Mycoplasma pneumoniae associated Opsoclonus-myoclonus syndrome in three cases. Eur J Pediatr. 2010;169:441-5. PMid:19774394. http://dx.doi.org/10.1007/s00431-009-1048-3

60. Loustalot MC, Savini H, Taugourdeau-Raymond S, Rouby F, Simon F, Jean-Pastor MJ. Opsoclonus-myoclonus syndrome in a young adult after a measles, mumps and rubella vaccine. Fundam Clin Pharmacol. 2012;26:114.

61. Steere AC, Malawista SE, Snydman DR, et al. Lyme arthritis: an epidemic of oligoarticular arthritis in children and adults in three Connecticut communities. Arthritis Rheum. 1977;20:717. http://dx.doi.org/10.1002/art.1780200102

62. Elbaum-Garfinkle S. Close to home: a history of Yale and Lyme disease. Yale J Biol Med. 2011;84:103-8. PMid:21698040 PMCid:PMC3117402.

63. Burgdorfer W, Barbour AG, Hayes SF, Benach JL, Grunwaldt E, Davis JP. Lyme disease: a tick-borne spirochetosis? Science. 1982;216:317-9. http://dx.doi.org/10.1126/ science. 7043737

64. Franke J, Hildebrandt A, Dorn W. Exploring gaps in our knowledge on Lyme borreliosis spirochaetes: updates on complex heterogeneity, ecology, pathogenicity. Ticks Tick Bourne Dis. 2013;4:11-25. PMid:23246041. http://dx.doi. org/10.1016/j.ttbdis.2012.06.007

65. Stanek G, Wormser GP, Gray J, Strle F. Lyme borreliosis. Lancet. 2012;379:461-73. http://dx.doi.org/10.1016/S01406736(11)60103-7
66. Halperin JJ. Nervous system Lyme disease. J Neurol Sci. 1998;153:182-91. http://dx.doi.org/10.1016/S0022510X(97)00290-6

67. Mygland A, Ljstad U, Fingerle V, Rupprecht T, Schmutzhard, Steiner I. EFNS guidelines on the diagnosis and management of European Lyme neuroborreliosis. Eur J Neurol. 2010;17:816. PMid:19930447. http://dx.doi.org/10.1111/j.14681331.2009.02862.x

68. Yoshinari NH, Mantovani E, Bonoldi VLN, Marangoni RG, Gauditano G. Brazilian Lyme-like disease or BaggioYoshinari Syndrome: exotic and emerging Brazilian tickborne zoonosis. Rev Assoc Med Bras. 2010;56:363-9. Portuguese. PMid:20676548. http://dx.doi.org/10.1590/ S0104-42302010000300025

69. Miller MM, Müllegger RR, Spork KD, Stanek G. Lyme borreliosis of central nervous system (CNS) in children: a diagnostic challenge. Infection. 1991;19:273-8. http://dx.doi. org/10.1007/BF01644966

70. Djukik M, Schmidt-Samoa C, Lange P, et al. Cerebrospinal fluid findings in adults with acute Lyme neuroborreliosis. J Neurol. 2012;259:630-6. PMid:21898139 PMCid:PMC3319903. http://dx.doi.org/10.1007/s00415-011-6221-8

71. Gouveia EA, Alves MF, Mantovani E, Oyafuso LK, Bonoldi VLN, Yoshinari NH. Profile of patients with Baggio-Yoshinari syndrome admitted at "Instituto de Infectologia Emilio Ribas”. Rev Inst Med Trop São Paulo. 2010;52:297-303. PMid:21225212.

72. Shinjo SK, Gauditano G, Marchiori PE, et al. Neurological manifestations in Baggio-Yoshinari syndrome (Brazilian Lyme disease - like syndrome). Bras J Rheumatol. 2009;49:492505.

73. Mantovani E, Marangoni RG, Gauditano G, Bonoldi VLN, Yoshinari NH. Amplification of the flgE gene provides evidence for the existence of a Brazilian borreliosis. Rev Inst Med Trop São Paulo. 2012;54:153-7. http://dx.doi.org/10.1590/ S0036-46652012000300007

74. Pooja D, Clarke C, David S. A case of poststreptococcal psoclonus-myoclonus syndrome. Mov Disord. 2007;22:14901. PMid:17486621. http://dx.doi.org/10.1002/mds.21513

\section{Conflict of interest: None}

Submitted on: $30^{\text {th }}$ December 2013

Accepted on: $9^{\text {th }}$ March 2014

Correspondence: Divisão de Clínica Médica Hospital Universitário da Universidade de São Paulo

Av. Prof. Lineu Prestes, 2565 - Cidade Universitária - São Paulo/SP - Brazil

CEP: 05508-000 - Phone: +55 (11) 3091-9200

E-mail: angelina@usp.br 